\title{
ANALISIS FINANCIAL DISTRESS DENGAN MENGGUNAKAN BANKRUPTCY PREDICTION MODELS PADA EMITEN ROKOK PERIODE 2014-2018
}

\author{
Ani Wahyuningsih' ${ }^{1}$ Hartono $^{2}$, Rini Armin ${ }^{3}$ \\ Universitas Islam Majapahit \\ E-mail: aniw26@gmail.com
}

\begin{abstract}
Financial Distress is a condition of financial difficulties where if this happens to the company foa along period of time, the company is in the initial stages before bankruptcy. Bankruptcy is a state of being or a situation in which company failed to or not able to meet obligations because firm experienced lack of. If the company goes bankrupt there will be many parties who are harmed. Therefore it is necessary to conduct financial distress analysis for early warning. The research aims to determine the financial health of the cigarette sub-sector companies by analyzing financial distress using three bankruptcy prediction models with Altman Z-Score, Springate, Grover and to determine which of these three models has the highest level of accuracy. The data used in this research is the company's financial statements published on the Indonesia Stock Exchange website. The population in this research is the cigarette subsector companies listed on the Indonesia Stock Exchange in the 2014-2018 period. Based on the result of research shows that in the calculation Altman and Springate models, PT. Bentoel International Investama in the category of the company experiencing symptoms of bankruptcy. While in the Grover model calculation, all companies fall into category healthy companies. Of the three models that have the highest level of accuracy are Altman and Springate models by one hundred percent. This shows that Altman and Springate models have the correct prediction of the company correctly.
\end{abstract}

Keywords: Altman Z-Score, Financial Distress, Grover, Bankruptcy, Springate.

\begin{abstract}
ABSTRAK
Financial Distress merupakan suatu kondisi kesulitan keuangan yang mana jika hal ini terjadi pada perusahaan dalam jangka waktu yang lama, maka perusahaan berada di tahap awal sebelum terjadinya kebangkrutan. Kebangkrutan merupakan keadaan dimana perusahaan gagal atau tidak mampu lagi memenuhi kewajiban-kewajiban karena perusahaan mengalami kekurangan. Jika perusahaan mengalami kebangkrutan aka nada banyak pihak yang dirugikan. Maka dari itu perlu melakukan analisis financial distress untuk peringatan dini. Hasil analisis dapat digunakan untuk mengambil keputusan atau kebijakan di masa mendatang yang tepat untuk mengurangi risiko-risiko yang dihadapi. Penelitian ini bertujuan untuk mengetahui kesehatan keuangan perusahaan sub sektor rokok dengan menganalisis financial distress menggunakan tiga model prediksi kebangkrutan yakni Altman Z-Score, Springate, dan Grover serta untuk mengetahui dari ketiga model tersebut manakah yang memiliki tingkat keakuratan tertinggi. Data yang digunakan dalam penelitian ini adalah laporan keuangan perusahaan yang di publikasikan di situs website Bursa Efek Indonesia. Populasi dalam
\end{abstract}


penelitian ini adalah perusahaan sub sektor rokok yang terdaftar di Bursa Efek Indonesia periode 2014-2018. Berdasarkan hasil dari penelitian menunjukkan bahwa dalam perhitungan model Altamn Z-Score dan Springate, PT. Bentoel Internasional Investama Tbk masuk dalam kategori perusahaan yang mengalami gejala kebangkrutan. Sedangkan dalam perhitungan model Grover, semua perusahaan masuk dalam kategori perusahaan yang sehat. Dari ketiga model tersebut yang memiliki tingkat akurasi tertinggi merupakan model Altman dan Springate sebesar seratus persen. Hal ini menunjukkan bahwa model Altman dan Springate mempunyai ketepatan prediksi perusahaan dengan benar.

Kata Kunci: Altman Z-Score, Financial Distress, Grover, Kebangkrutan, Springate.

\section{PENDAHULUAN}

Ketidakmampuan perusahaan dalam mengantisipasi perkembangan global dapat memperlemah fundamental manajemen perusahaan. Hal tersebut akan mengakibatkan pengecilan dalam volume usaha yang pada akhirnya akan mengakibatkan kebangkrutan perusahaan. Kebangkrutan ialah keadaan di mana perusahaan telah dianggap gagal dalam mempertahankan bisnisnya.

Industri rokok masih memberikan kontribusi yang signifikan terhadap perekonomian Indonesia. Selain sebagai motor penggerak perekonomian Indonesia, industri rokok juga mempekerjakan banyak tenaga kerja, sumber pendapatan negara yang tinggi juga dari pajak rokok, serta menjadi komoditas penting bagi petani tembakau. Kementerian Perindustrian (Kemenperin) mencatatkan, pendapatan negara dari industri rokok yang berasalkan dari tarif cukai dan pajak setiap tahunnya mengalami peningkatan. (Dni, 2017)

Pada tanggal 13 September 2019, usai menggelar rapat secara tertutup di Istana Kepresidenan, Jakarta. Sri Mulyani Indrawati selaku Menteri Keuangan mengemukakan kenaikan tarif cukai rokok atau Cukai Hasil Tembakau (CHT) rata-rata sebesar 21,55\% yang berlaku mulai tahun depan pada tanggal 1 Januari 2020. Dengan kenaikan tarif cukai tersebut harga jual rokok eceran juga mengalami kenaikan sebesar $35 \%$. Keputusan ini akan dicatatkan dalam Peraturan Menteri Keuangan atau PMK Nomor 152/PMK.010/2019. (Dwi dan Cantika, 2019)

\begin{tabular}{cc} 
Tabel 1 Persentase Kenaikan Tarif Cukai \\
\hline Tahun & Tarif Cukai \\
\hline 2013 & $8,50 \%$ \\
\hline 2014 & - \\
\hline 2015 & $8,75 \%$ \\
\hline 2016 & $11,19 \%$ \\
\hline 2017 & $10,54 \%$ \\
\hline 2018 & $10,04 \%$
\end{tabular}

Sumber: Databoks, 2020

Kenaikan tarif cukai bukan hal yang luar biasa. Secara regular, pemerintah menaikkan tarif cukai rokok hampir setiap tahun. Dari tahun 2015 hingga 2018 rata-rata kenaikan tarif cukai rokok sebesar $10 \%$.

Kenaikan tarif cukai rokok tentunya akan berdampak pada peforma saham emiten rokok termasuk PT. Gudang Garam Tbk yang sahamnya masih menunjukkan tren 
penurunan. Riset PT. Danareksa Sekuritas seperti dikutip Bisnis.com, pada sabtu 28 Maret 2015, menuturkan saham emiten berkode GGRM itu sudah mengalami penurunan sejak awal 2015, seiring munculnya berita kenaikan tarif cukai rokok. (Anisa Margrit, 2015)

Pada industri rokok ini perlu diprediksi suatu financial distress yang mungkin terjadi dilihat dari kebijakan pemerintah dan harga saham emiten rokok yang menurun drastis. Salah satu indikator financial distress yang dapat diamati oleh piahk eksternal yakni harga saham di pasar modal yang turun secara terus menerus. Industri rokok merupakan salah satu industri yang mengalami pasang surut namun, tetap eksis di Indonesia. Pertumbuhan ekonomi yang lamban bahkan sempat minus dimasa krisis ternyata tidak mempengaruhi industri rokok di Indonesia. Padahal industri rokok di Indonesia mengalami banyak tantangan karena imbas krisis yang berkepanjangan. Seperti halnya, daya beli masyarakat yang menurun, tarif cukai yang terus merambat naik, upah buruh mengalami penyesuaian sesuai dengan tuntutan biaya hidup yang semakin tinggi.

Cara yang lebih sering digunakan oleh perusahaan yaitu menganalisis kesehatan keuangan perusahaan, di mana perusahaan dapat memeprediksi kemungkinan adanya Financial Distress. Diantaranya dengan menggunakan Bankruptcy Prediction Models yang terdiri dari beberapa model yaitu Altman Z-Score, Springate, dan Grover. Model ini dikenal karena mudah dalam penerapannya.

Beberapa penelitian menyimpulkan hasil penerapan model prediksi kebangkrutan yang berbeda-beda. Berdasarkan penelitian Abdul dan Nardi (2018) meneliti prediksi kebangkrutan model Altman Z-Score dengan sampel bank pemerintah (BUMN). Hasil penelitian menunjukkan, tahun 2012 hingga 2016 terdapat empat bank pemerintah yang diprediksi berada pada kondisi Gray Area (Rawan) dengan nilai Z sebesar 2,03.

Ditiro (2015) menggunakan model Springate untuk memprediksi perusahaan property dan real estate yang terdaftar di BEI. Hasilnya dari total 27 perusahaan yang diteliti, terdapat 8 perusahaan yang diprediksi berada dalam kondisi sehat. Ada 9 perusahaan yang mengalami kebangkrutan selama 3 tahun yakni pada tahun 2011 sampai dengan 2013. Lima perusahaan mengalami perubahan kategori dari perusahaan yang diprediksi berpotensi bangkrut menjadi perusahaan yang diprediksi berada pada kondisi sehat. Dan terakhir terdapat 5 perusahaan yang mengalami perubahan kondisi dari perusahaan yang diprediksi sehat menjadi perusahaan yang diprediksi mengalami gejala bangkrut.

Michael (2016) melakukan penelitian menggunakan model Grover dengan sampel perusahaan pertambangan dan pertanian yang go public. Hasil dari penelitian sektor pertanian dan pertambangan mengalami penurunan. Meskipun semua perusahaan mengalami penurunan dalam segi pendapatan, semua perusahaan tersebut tetap bisa bertahan dan ada satu perusahaan yang diprediksi mengalami kebangkrutan yakni PT. Bumi Resources Tbk.

Dari hasil penelitian sebelumnya terdapat perbedaan hasil dari penerapan model prediksi yang berbeda. Dengan diketahui model-model prediksi yang tepat, diharapkan investor maupun pihak-pihak lain yang berkepentingan dalam analisis kesulitan keuangan dapat mengambil keputusan dengan lebih baik. Perbedaan penelitian ini dengan penelitian sebelumnya adalah pada penelitian ini menggunakan 3 model prediksi di atas, yakni Altman Z-Score, Springate, dan Grover. Kemudian untuk mengetahui mana model yang akurat maka dilakukan perhitungan tingkat akurasi setiap model. 
Berdasarkan uraian di atas, hal ini menjadi penting untuk melakukan penelitian terkait kondisi Financial Distress perusahaan manufaktur sub sektor rokok yang berefek pada minat investor untuk melakukan investasi yang disinyalir mempengaruhi harga saham perusahaan. Dengan demikian, penulis termotivasi melakukan penelitian dengan judul "Analisis Financial Distress Dengan Menggunakan Bankruptcy Prediction Models Pada Emiten Rokok Periode 2014-2018".

Berdasarkan latar belakang di atas maka penulis merumuskan masalah yang akan dibahas dalam penelitian ini yaitu: (1) Bagaimana memprediksi Financial Distress dengan menggunakan model Altman Z-Score, Springate, dan Grover pada emiten rokok tahun 2014-2018? (2) Manakah di antara model Altman Z-Score, Springate, dan Grover yang memiliki keakuratan tertinggi?.

Tujuan dari penelitian ini yaitu: (1) Untuk mengetahui prediksi Financial Distress dengan menggunakan model Altman Z-S core, Springate, dan Grover pada emiten rokok tahun 2014-2018 (2) Untuk mengetahui mana di antara model Altman Z-Score, Springate, dan Grover yang memiliki keakuratan tertinggi.

\section{LANDASAN TEORI}

Variabel yang berhubungan dengan teori adalah pembahasan yang menjadi fokus dalam suatu penelitian. Berikut adalah variabel yang berhubungan dengan teori penulisan:

\section{Laporan Keuangan}

Informasi kuantitatif dari sebuah perusahaan dalam periode waktu tertentu dan hasil dari sebuah proses akuntansi yang bertujuan untuk memberikan informasi perusahaan yang dibutuhkan oleh stake holder dan pihak lain yang membutuhkan sebagai dasar pengambilan keputusan ekonomi merupakan pengertian laporan keuangan. (Pirmatua Sirait, 2017:2).

\section{Analisa Laporan Keuangan}

Analisa laporan keuangan adalah model dan teknik analisis atas laporan keuangan yang berfungsi untuk mengkonversikan data yang berasal dari laporan keuangan sebagai bahan mentahnya menjadi informasi yang lebih berguna, lebih mendalam, dan lebih tajam dengan teknik tertentu. Tujuan pokok analisa keuangan adalah analisa kinerja kuangan di masa yang akan datang.

\section{Kesulitan Keuangan (Financial Distress)}

Farida (2019:3) menyatakan bahwa kesulitan keuangan merupakan situasi di mana suatu perusahaan tidak mampu dalam membayar kewajibannya. Hal inilah yang menjadi tanda awal sebelum terjadinya risiko yang paling buruk, yakni kebangkrutan. Indikator financial distress suatu perusahaan menurut Teng (2002) dalam Nufal Syaifudin (2012) sebagai berikut: Penurunan jumlah dividen bahkan perusahaan tidak membagikan kepada pemegang saham dan Harga saham yang terus menerus turun di pasar modal.

Sedangkan menurut Platt dan Platt (2002) dalam Gobenvy (2013), suatu perusahaan mengalami financial distress dapat diindikasi dari: Perusahaan mempunyai nilai Earning Per Share negative dan Penurunan laba bahkan perusahaan memilki net income negatif.

\section{Kebangkrutan}


Menurut Undang-undang RI No. 4 Tahun 1998, kebangkrutan merupakan keadaan di mana suatu institusi dinyatakan pailit oleh keputusan pengadilan, bila debitur memiliki dua atau lebih kreditur dan tidak membayar sedikitnya satu utang yang telah jatuh tempo. Kegagalan perusahaan dalam menjalankan operasi perusahaan untuk menghasilkan laba juga dapat disebut kebangkrutan.

\title{
Model Altman Z-Score
}

Model prediksi kesulitan keuangan multivariate yang dikembangkan oleh Altman (1968). Z-Score pertama kali dikembangkan untuk menentukan kecenderungan kesulitan keuangan dapat juga digunakan sebagai ukuran keseluruhan kinerja keuangan perusahaan. Altman telah mengkombinasikan beberapa rasio menjadi model prediksi dengan teknik statistik, yakni analisis diskriminan, yang digunakan untuk memprediksi kesulitan keuangan perusahaan menggunakan istilah yang dikenal dengan Z-Score.

Menurut Hanafi dan Halim (2005:275) dalam Rafles (2015:5) menjelaskan bahwa pada tahun 1983 dan 1984, model Altamn Z-Score dikembangkan lagi oleh Altman untuk beberapa negara, dari penelitian tersebut ditemukan nilai $\mathrm{Z}$ yang baru untuk perusahaan yang go public, dan ternyata model Altman memiliki tingkat kevalidan hingga 95\%, dengan persamaan diskriminan sebagai berikut:

$$
Z=1.2 X 1+1.4 X 2+3.3 X 3+0.6 X 4+1.0 X 5
$$

\author{
Keterangan: \\ $\mathrm{Z}=$ Bankruptcy Index \\ $\mathrm{X} 1=$ Working Capital to Total Asset \\ $\mathrm{X} 2=$ Retained Earning to Total Asset \\ X3 = Earning Before Interest and Taxes (EBIT) to Total Asset \\ X4 = Market Value of Equity to Book Value of Total Liabilities \\ $\mathrm{X} 5$ = Sales to Total Asset
}

Nilai $\mathrm{Z}$ adalah indeks keseluruhan fungsi multiple discriminant analysis. Terdapat angka-angka cut-off nilai $\mathrm{Z}$ yang dapat menjelaskan apakah perusahaan akan mengalami kesulitan keuangan atau tidak pada masa mendatang, terbagi ke dalam tiga kategori yaitu:

a. Jika nilai $\mathrm{Z}<1.81$ maka perusahaan yang diprediksi berada pada kondisi bangkrut (Bankrupt)

b. Jika nilai $1.81>\mathrm{Z}<2.99$ maka perusahaan yang diprediksi berada di kondisi rawan (Gray Area)

c. Jika nilai $Z>2.99$ maka perusahaan berada pada kondisi sehat (Non Bankruptcy)

\section{Model Springate}

Menurut Peter dan Yoseph (2011), dalam Ben et.al (2015;3), model ini dikembangkan oleh Gorgon .L .V Springate, yang melakukan penelitian untuk menemukan model yang dapat digunakan dalam memprediksi adanya potensi atau indikasi kebangkrutan. Springate akhirnya menemukan empat rasio yang dapat digunakan dalam memprediksi adanya potensi atau indikasi kebangkrutan perusahaan. Empat rasio tersebut dirumuskan sebagai berikut:

$$
S=1.03 X 1+3.07 X 2+0.66 X 3+0.4 X 4
$$


Keterangan:

$\mathrm{X} 1=$ Working Capital to Total Asset

$\mathrm{X} 2=$ Net Profit Before Interest and Taxes to Total Asset

$\mathrm{X} 3=$ Net Profit Before Taxes to Current Liability

$\mathrm{X} 4=$ Sales to Total Asset

Klasifikasi perusahaan yang sehat dan bangkrut didasarkan pada nilai S-Score model Springate, yaitu:

a. Skor $\mathrm{S}>0.862$ diklasifikasikan sebagai perusahaan yang sehat.

b. Skor $\mathrm{S}<0.862$ diklasifikasikan perusahaan tersebut tidak sehat dan berpotensi bangkrut.

\section{Model Grover}

Model yang diciptakan dengan melakukan pendesainan ulang terhadap model Altman. Jeffrey .S Grover (2001) dalam Prihatini dan Sari (2013) menghasilkan fungsi persamaan sebagai berikut:

$$
G=1,650 X 1+3,404 X 3-0,016 R O A+0,057
$$

Keterangan:

$\mathrm{X} 1=$ Working Capital to Total Asset

$\mathrm{X} 2=$ Earnings Before Interest and Taxes to Total Asset

$\mathrm{ROA}=$ Net Income to Total Asset

Klasifikasi perusahaan dalam keadaan sehat dan bangkrut didasarkan pada nilai G-Score model Grover, yaitu:

a. Skor $\mathrm{G} \leq-0.02$ perusahaan dalam keadaan tidak sehat, mengalami indikasi kebangkrutan.

b. Skor $G \geq 0.01$ perusahaan dalam kondisi yang sehat.

\section{Model Ohlson}

Model ini ditemukan oleh James Ohlson pada tahun 1980. Ohlson menciptakan model ini berdasarkan penelitiannya pada tahun 1970-1976, dengan sampel 105 perusahaan bangkrut dan 2.058 perusahaan sehat. Menurut Ghozali (2011) model yang dibangun oleh Ohlson memiliki sembilan variabel yang terdiri dari beberapa rasio keuangan. Model tersebut dirumus sebagai berikut:

$$
\begin{gathered}
O=-1.32-0.407 X 1+6.03 X 2-1.43 X 3+0.0757 X 4-2.37 X 5 \\
-1.83 X 6+0.285 X 7-1.72 X 8-0.521 X 9
\end{gathered}
$$

Keterangan:

$\mathrm{X} 1=\log ($ Total Aset/Indeks Tingkat Harga GNP $)$

$\mathrm{X} 2=$ Total Utang/Total Aset

X3 = Modal Kerja/Total Aset

X4 = Utang Lancar/Aktiva Lancar

X5 = 1 Jika Total Utang > Total Aset ; 0 Jika sebaliknya

X6 = Laba Bersih/Total Aktiva

$\mathrm{X} 7=$ Arus Kas Operasi/Total Utang

$\mathrm{X} 8=1$ Jika Laba Bersih negative untuk dua tahun terakhir; 0 Jika sebaliknya

$\mathrm{X} 9=($ Laba Bersih tahun $\mathrm{t}-$ Laba Bersih tahun $\mathrm{t}-1) /($ Laba Bersih tahun $\mathrm{t}+$

Laba Bersih tahun t-1) 
Klasifikasi perusahaan yang sehat dan bangkrut didasarkan pada model Ohlson yaitu:

a. Untuk nilai $\mathrm{O}<0.38$ artinya perusahaan sehat secara keuangan.

b. Untuk nilai $\mathrm{O} \geq 0.38$ maka perushaan masuk dalam kondisi yang tidak sehat.

\section{Model Zmijewski}

Menurut Peter dan Yoseph dalam Etta dan Made (2014:7) perluasan studi dalam prediksi kebangkrutan yang dilakukan oleh Zmijewski (1984) menambah validitas rasio sebagai alat deteksi kegagalan keuangan perusahaan. Zmijewski melakukan studi dengan menelaah ulang studi bidang kebangkrutan hasil riset sebelumnya selama dua puluh tahun. Model yang berhasil dikembangkan yaitu:

$$
X=-4.3-4.5 X 1+5.7 X 2-0.004 X 3
$$

$$
\begin{aligned}
& \text { Keterangan: } \\
& \text { X1 = ROA } \\
& \text { X2 = Debt Ratio } \\
& \text { X3 = Current Ratio }
\end{aligned}
$$

Klasifikasi perusahaan yang berada di kondisi sehat dan bangkrut didasarkan pada model Zmijewski, yaitu:

a. Jiak $X<0$ maka perusahaan tersebut digolongkan dalam kondisi yang sehat.

b. Jika $X>0$ maka perusahaan dapat digolongkan dalam kondisi yang tidak sehat atau cenderung mengarah ke kebangkrutan.

\section{Tingkat Akurasi}

Setiap model prediksi selalu terdapat kemungkinan salah prediksi dan perbedaan tingkat akurasi. Untuk menilai model financial distress mana yang merupakan predictor terbaik di antara ketiga model tersebut perlu dilakukan perhitungan tingkat akurasi hasil prediksi setiap model. Menurut Prihadi (2010:334) dalam Gerdian (2016:21), model prediksi dikatakan benar apabila antara yang diprediksi dengan keadaan sebenarnya sama, sebaliknya terjadi kesalahan apabila antara yang diprediksi dengan keadaan sebenarnya berbeda. Tingkat akurasi tiap model dihitung dengan cara sebagai berikut:

$$
\text { Tingkat Akurasi }=\frac{\text { Jumlah Prediksi Benar }}{\text { Jumlah Sampel }} \times 100 \%
$$

\section{METODE PENELITIAN}

\section{Desain Penelitian}

Jenis penelitian ini merupakan deskriptif kuantitatif, dengan cara menganalisis data-data laporan keuangan yang kemudian ditabulasikan untuk menentukan kategori perusahaan. Penelitian in tidak menggunakan uji statistik sehingga kesimpulan yang dibuat berdasarkan kriteria atau standar yang ditentukan. (Arikunto, 2010:386).

Data yang akan diolah dalam penelitian ini merupakan laporan keuangan yang dapat di akses dari situs website resmi Bursa Efek Indonesia www.idx.co.id dan website resmi perusahaan terkait selama periode penelitian. 


\section{Populasi}

Objek dalam penelitian ini merupakan perusahaan sub sektor rokok yang terdaftar di Bursa Efek Indonesia pada periode tahun 2014 sampai dengan tahun 2018. Metode pengambilan sampel yang digunakan yakni sampling jenuh, hal tersebut menunjukkan sampel yang digunakan dalam penelitian ini merupakan populasi yang ada. Adapun perusahaan-perusahaan yang menjadi objek dalam penelitian ini sebagai barikut:
a. PT. Gudang Garam Tbk
b. PT. Handjaya Mandala Sampoerna Tbk
c. PT. Bentoel Internasional Investama Tbk
d. PT. Wismilak Inti Makmur Tbk

\section{Variabel dan Definisi Operasional Variabel}

Variable yang digunakan dalam penelitian ini merupakan rasio-rasio model Altman Z-Score, Springate, dan Grover.

Tabel 2 Definisi Operasional Variabel

\begin{tabular}{|c|c|c|c|}
\hline Variabel & p Dasar & Rumus & Sk \\
\hline WCTA & $\begin{array}{l}\text { Menunjukkan kemampuan perusahaan untuk } \\
\text { menghasilkan modal kerja bersih dari keseluruhan } \\
\text { aktiva yang dimiliki perusahaan. }\end{array}$ & $\frac{C A-C L}{T A}$ & Rasio \\
\hline RETA & $\begin{array}{l}\text { Menunjukkan } \\
\text { menghasilkan laba ditahan } \\
\text { perusahaan. }\end{array}$ & $\frac{R E}{T A}$ & Rasio \\
\hline EBITTA & $\begin{array}{l}\text { Mengukur produktivitas yang sebenarnya dari } \\
\text { perusahaan. }\end{array}$ & $\frac{E B I T}{T A}$ & Rasio \\
\hline MVEB & $\begin{array}{l}\text { Menunjukkan kemampuan perusahaan untuk } \\
\text { memenuhi kewajibannya dari nilai pasar modal } \\
\text { sendiri. }\end{array}$ & $\frac{M V E B V}{T L}$ & Rasio \\
\hline STA & 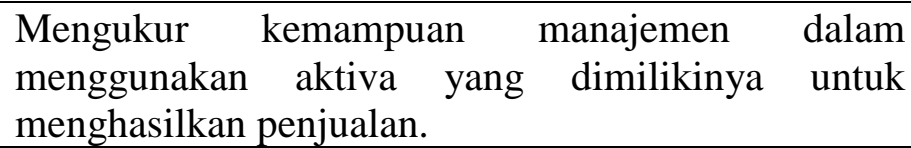 & $\frac{S}{T A}$ & Rasio \\
\hline NPBTCL & $\begin{array}{l}\text { Mengukur kemampuan perusahaan dalam melunasi } \\
\text { hutang jangka pendeknya. }\end{array}$ & $\frac{E B T}{C L}$ & Rasio \\
\hline ROA & $\begin{array}{l}\text { Mengukur seberapa efisien suatu perusahaan dalam } \\
\text { mengelola asetnya untuk menghasilkan laba selama } \\
\text { suatu periode. }\end{array}$ & $\frac{E A T}{T A}$ & Rasio \\
\hline
\end{tabular}

\section{Teknik Analisis Data}

Alat analisis yang digunakan dalam penelitian ini merupakan Bankruptcy Prediction Models. Dalam penelitian ini perlu dilakukan pengolahan data. Berikut langkah-langkah pengolahan data:
a. Mengumpulkan Data
b. Menghitung Rasio-rasio Model Prediksi
c. Menerapakan Model Prediksi
d. Membuat Hasil Tabel Perhitungan Model Prediksi 
e. Menghitung Tingkat Akurasi Model Prediksi

\section{HASIL DAN PEMBAHASAN}

\section{Penerapan Model Prediksi}

Terdapat empat perusahaan yang menjadi objek dalam penelitian ini. Perusahaaan yang menjadi objek penelitian diteliti selama periode 2014-2018, yakni liam tahun. Dari empat perusahaan, ada satu perusahaan yang tidak membagikan dividen ke pemegang saham, perusahaan yang mengalami kerugian berturut-turut, dan perusahaan yang mempunyai EPS negatif merupakan perusahaan yang masuk dalam kondisi financial distress. Perusahaan tersebut adalah PT. Bentoel Internasional Investama Tbk. Sedangkan sisanya tidak mengalami kondisi financial distress.

Tabel 3 Hasil Penerapan Model Altman Z-Score

\begin{tabular}{ccccccccc}
\hline No & Kode & \multicolumn{5}{c}{ Nilsi Z } & Rata- & Keterangan \\
\cline { 3 - 7 } & Emiten & 2014 & 2015 & 2016 & 2017 & 2018 & rata & \\
\hline 1. & GGRM & 5,44 & 5,29 & 6,13 & 6,99 & 7,25 & 6,22 & Sehat \\
\hline 2. & HMSP & 17,49 & 48,50 & 36,75 & 41,26 & 27,65 & 34,33 & Sehat \\
\hline 3. & RMBA & 1,25 & 1,2 & 1,71 & 1,91 & 2,31 & 1,64 & Bangkrut \\
\hline 4. & WIIM & 4,14 & 4,25 & 4,22 & 3,91 & 3,21 & 3,95 & Sehat \\
\hline
\end{tabular}

Sumber: Data diolah oleh penulis.

Dari tabel 3 Hasil penerapan model Altman Z-Score, nilai $\mathrm{Z}$ di atas menunjukkan bahwa kondisi keuangan PT. Gudang Garam Tbk menunjukkan posisi perusahaan berada pada kondisi yang sehat selama liam tahun, mulai dari tahun 2014 sampai dengan tahun 2018. Hal ini menujukkan PT. Gudang Garam Tbk mampu mempertahankan kinerjanya dengan baik sheingga terhindar dari kesulitan keuangan yang dapat menjadi tahap awal kebangkrutan. Selain PT. Gudang Garam Tbk, perusahaan lain yang memperoleh nilai Z-Score rata-rata lebih dari 2,99 yakni PT. Handjaya Mandala Sampoerna Tbk dan PT. Wismilak Inti Makmur Tbk yang juga berada dalam kondisi sehat. Pada tahun 2014, PT. Bentoel Internasional Investama Tbk berada pada kondisi adanya gejala bangkrut karena memiliki niali $\mathrm{Z}$ kurang dari 1,81 yaitu sebesar 1,64.

Tabel 4 Hasil Penerapan Model Springate

\begin{tabular}{ccccccccc}
\hline \multirow{2}{*}{ No } & Kode & \multicolumn{5}{c}{ Nilai S } & Rata- & \multirow{2}{*}{ Keterangan } \\
\cline { 3 - 8 } & Emiten & 2014 & 2015 & 2016 & 2017 & 2018 & Rata & \\
\hline 1. & GGRM & 1,36 & 1,47 & 1,58 & 1,66 & 1,71 & 1,56 & Sehat \\
\hline 2. & HMSP & 3,56 & 4,96 & 4,55 & 4,60 & 4,01 & 4,34 & Sehat \\
\hline 3. & RMBA & 0,32 & 0,29 & 0,53 & 0,78 & 0,77 & 0,054 & Bangkrut \\
\hline 4. & WIIM & 1,53 & 1,73 & 1,65 & 1,41 & 1,49 & 1,56 & Sehat \\
\hline \multicolumn{6}{l}{ Sumber: Data dioleh oleh penulis. }
\end{tabular}

Hasil penerapan menggunakan model Springate dapat dilihat bahwa kondisi keuangan empat perusahaan sub sektor rokok yang diteliti, ditemukan tiga perusahaan yang berada dalam kondisi sehat selama tahun 2014 hingga tahun 2018 yaitu PT. Gudang Garam Tbk, PT. Handjaya Mandala Sampoerna Tbk, dan PT. Wismilak Inti 
Makmur Tbk. masing-maisng perusahaan memperoleh nilai $\mathrm{S}$ lebih dari 0,862. Dari ketiganya nilai S PT. Handjaya Mandala Sampoerna Tbk yang tertinggi sebesar 4,34 rata-rata per tahun. Berbeda dengan tiga perusahaan di atas, PT. Bentoel Internasional Investama Tbk mengalami kondisi gejala bangkrut selama lima tahun sejak 2014 hingga 2018. Nilai $S$ yang diperoleh kurang dari 0,862 yakni sebesar 0,054. Hal ini menunjukkan bahwa manajemen perusahaan sebaiknya segera berbenah agar perusahaan mampu keluar dari kondisi tersebut.

Tabel 5 Hasil Penerapan Model Grover

\begin{tabular}{ccccccccc}
\hline \multirow{2}{*}{ No } & Kode & \multicolumn{5}{c}{ Nilai G } & Rata- & Keterangan \\
& Emiten & 2014 & 2015 & 2016 & 2017 & 2018 & Rata & Sehat \\
\hline 1. & GGRM & 0,98 & 1,08 & 1,13 & 1,16 & 1,16 & 1,10 & Sehat \\
\hline 2. & HMSP & 2,14 & 2,40 & 2,41 & 2,38 & 2,31 & 2,33 & Sehat \\
\hline 3. & RMBA & 0,02 & 0,36 & 0,48 & 0,5 & 0,42 & 0,36 & Sehat \\
\hline 4. & WIIM & 1,16 & 1,36 & 1,26 & 1,13 & 1,17 & 1,22 & Sehat \\
\hline \multicolumn{6}{c}{ Sumber: Data diolah oleh penulis. }
\end{tabular}

Tabel 4.3 menunjukkan hasil penerapan model Grover pada perusahaan sub sektor rokok pada tahun 2014 samapi dengan tahun 2018, semua perusahaan berada pada kondisi sehat karena memperoleh nilai $G$ rata-rata per tahun lebih dari 0,01. Di antara perusahaan tersebut, PT. Handjaya Mandala Sampoerna Tbk memiliki nilai G rata-rata tertinggi sebesar 2,33. Berdasarkan kriteria model Grover menyatakan secara keseluruhan, perusahaan rokok memiliki kondisi keuangan yang sehat dan menunjukkan kinerja keuangan yang baik.

\section{Perhitungan Tingkat Akurasi}

Berdasarkan hasil perhitungan tingkat akurasi di atas menujukkan bahwa model Altman memiliki tingkat akurasi ketepatan sebesar 100\% dengan sebnayak empat perusahaan yang diprediksi sesuai dengan keadaan yang sebenarnya. Model Altman ini memprediksi satu perusahaan berada pada kondisi mengalami gejala bangkrut sesuai dengan keadaan sebenarnya yang menurut indikator mengalami financial distress. Sebanyak tiag perusahaan ada pada kondisi sehat yang sesuai dengan keadaan sebenarnya perusahaan memiliki keuangan sehat.

Tabel 6 Tingkat Akurasi Model Altman

\begin{tabular}{ccc}
\hline & \multicolumn{2}{c}{ Hasil Penerapan Model } \\
\cline { 2 - 3 } & Bangkrut & Sehat \\
\hline Kenyataan & & \\
\hline Baangkrut & 1 & - \\
\hline Sehat & - & 3 \\
\hline
\end{tabular}

Sumber: Data diolah oleh penulis.

$$
\begin{aligned}
\text { Tingkat Akurasi } & =\frac{\text { Jumlah Prediksi Benar }}{\text { Jumlah Sampel }} \times 100 \% \\
& =\frac{3+1}{4} \times 100 \% \\
& =100 \%
\end{aligned}
$$


Model Springate memiliki tingkata kurasi ketepatan sebesar 100\%. Dengan sebanyak empat perusahaan yang diprediksi tepat sesuai dengan keadaan sebenarnya. Hasil model Springate ini memprediksi tiga perusahaan berada dalam kondisi sehat dan sisanya mengalami gejala kebangkrutan.

Tabel 7 Tingkat Akurasi Model Springate

\begin{tabular}{ccc}
\hline & \multicolumn{2}{c}{ Hasil Penerapan Model } \\
\cline { 2 - 3 } & Bangkrut & Sehat \\
\hline Kenyataan & & \\
\hline Bangkrut & 1 & - \\
\hline Sehat & - & 3 \\
\hline
\end{tabular}

Sumber: Data diolah oleh penulis.

$$
\begin{aligned}
\text { Tingkat Akurasi } & =\frac{1+3}{4} \times 100 \% \\
& =100 \%
\end{aligned}
$$

Hasil perhitungan tingkat akurasi model Grover menunjukkan bahwa model Grover memiliki tingkat akurasi ketepatan sebesar $75 \%$ dengan sebanyak tiga perusahaan yang diprediksi sesuai keadaan sebenarnya. Hasil dari model Grover ini memprediksi tiga perusahaan berada pada kondisi sehat sesuai dengan keadaan keuanga yang dimiliki perusahaan.

Tabel 8 Tingkat Akurasi Model Grover

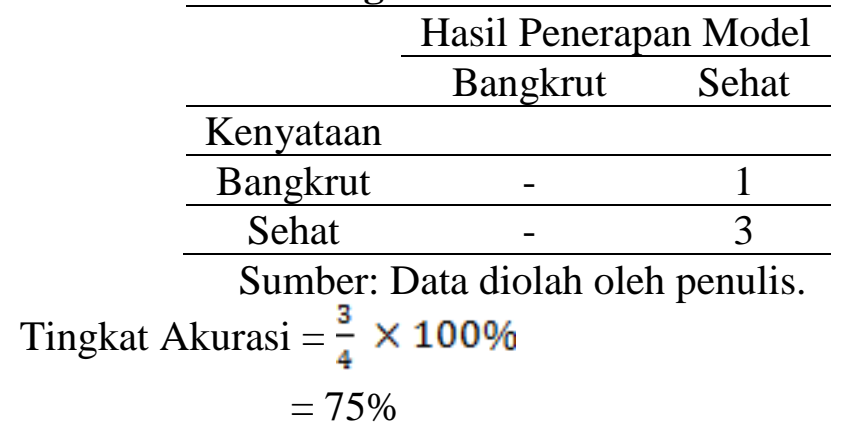

\section{KESIMPULAN}

Terdapat perbedaan haisl prediksi kebangkrutan antar model Altman, Springate dan Grover dalam analisis financial distress. Setiap model memberikan hasil prediksi yang saling berbeda. Hal ini dikarenakan setiap model memiliki perhitungan rasio keuangan dan nilai cut-off yang berbeda-beda. Dalam hasil penerapan model Altamn dan Springate menyatakan PT. Bentoel Internasional Investama Tbk masuk dalam kondisi perusahaan yang mengalami gejala kebangkrutan, karena perusahaan mengalami financial distress menurut indikasi yang terjadi. Sedangkan pada penerapan model Grover, semua perusahaan berada dalam kondisi sehat.

Model Altman dan Springate merupakan model yang memiliki tingkat akurasi tertinggi dibandingkan model Grover. Tingakt akurasi model Altman dan Springate sebesar seratus persen (100\%). Tingkat akurasi tertinggi menunjukkan bahwa model Altman dan Springate mempunyai ketepatan prediksi perusahaan dengan benar. Jika 
prediksi menyatakan bangkrut, amak terjadi permasalahan dalam keuangan perusahaan tersebut. Namun, jika prediksi menyatakan tidak bangkrut maka perusahaan memiliki kondisi keuangan yang sehat.

\section{REFERENSI}

Aben, D. A. (2015). Analisis Metode Springate (S-Score) Sebagai Alat Untuk Memprediksi Kabngkrutan Perusahaan. Jurnal Administrasi Bisnis. Vol. 21. No. 1:3.

Altman, E., dan Hotckiss, E. (2006). Corporate Fianancial Distress and Bankruptcy. Third Edition.

Arikunto, Suharsimi. (2010). Prosedur Penelitian Suatu Pendekatan Praktik. Jakarta: Rhineka Cipta.

CNBC Indonesia. (2019). Sri Mulyani Naikkan Cukai Rokok 21,55\% 1 Januari 2020. 23 Oktober 2019. https://www.cnbcindonesia.com/news Visitasi: 15 November 2019.

Gerdian, P. (2016). Analisis Akurasi Metode Altman, Grover, Springate, dan Zmijewski dalam Memprediksi Perusahaan Delisting (Studi Empiris Pada Perusahaan Manufaktur di BEI Periode 2009-2013). Skripsi. Universitas Sanata Dharma.

Hanfi, Mamduh M dan Abdul Halim. (2000). Analisis Laporan Keuangan. Yogyakarta: UPP STIM YKPN.

Kristanti, F.T. (2019). Financial Distress. Malang: Inteligensia Media.

Koran Sindo. (2017). Industri Rokok Punya Peranan Dalam Perekonomian Nasional. 11 Maret 2017. https://economy.okezone.com Visitasi: 15 November 2019.

Platt, H, dan M. B. Platt. (2002). Predicting Financial Distress. Journal of Financial Service Profesionals. Hal. 12-15.

Ptihanthini, N. M. (2013). Prediksi Kebangkrutan dengan Model Grover, Altman ZScore, Springate, dan Zmijewski pada Perusahaan Food and Beverage di Bursa Efek Indonesia. E-Jurnal Akuntansi Universitas Udayana. Vol. 52, 420-423.

Sirait, Primatua. (2017). Analisis Laporan Keuangan. Yogyakarta: Ekuilibria. 